CHAPTER 1

\title{
INTRODUCTION TO PETROLEUM-RELATED GEOLOGIC STUDIES IN LOWER COOK INLET DURING 2015, INISKIN-TUXEDNI REGION, SOUTH-CENTRAL ALASKA
}

\author{
Trystan M. Herriott ${ }^{1}$, editor
}

\section{INTRODUCTION}

Lower Cook Inlet of south-central Alaska has long been recognized to host oil and gas, with hydrocarbon seeps noted on the Iniskin Peninsula as early as the mid-nineteenth century (Martin, 1905) (fig. 1-1). Drilling near these seeps commenced in 1900; continued exploration through 1960 also examined nearby structural culminations (Detterman and Hartsock, 1966). Although no commercial discoveries were made despite oil and gas shows in these wells (Blasko, 1976), the Iniskin-Tuxedni bays region remains important, permitting examination of the basin margin's Mesozoic stratigraphy and structure along an $\sim 80 \mathrm{~km}$ outcrop belt (figs. 1-2 and 1-3). These exposures include Middle Jurassic strata that are age-equivalent to probable source rocks for oil produced from fields in upper Cook Inlet (see LePain and others, 2013). Furthermore, this onshore area is important to understanding the potential for commercial accumulations of hydrocarbons in Mesozoic strata of Cook Inlet. Notably, a recent resource estimate indicates significant oil and gas volumes remain likely to be discovered in Cook Inlet (Stanley and others, 2011), and industry-led exploration on the Iniskin Peninsula resumed in 2013 (Nelson, 2014).

Within this context, the Alaska Division of Geological \& Geophysical Surveys (DGGS), in collaboration with the Alaska Division of Oil and Gas and U.S. Geological Survey, initiated a lower Cook Inlet research program in 2009. This work aims to further delineate the geology of this economically important region and is ongoing in continued recognition of the critical energy needs of south-central Alaska and the fact that the Cook Inlet forearc basin is underexplored despite a nearly 60 year oil and gas production history. The DGGS-led field investigations in the Iniskin-Tuxedni area build on the seminal study of Detterman and Hartsock (1966) and focus on modern sedimentologic, stratigraphic, and structural analyses, as well as new 1:63:360-scale geologic mapping (see below), to better characterize petroleum potential.

This volume constitutes the fourth annual publication of a collection of short papers regarding our work in lower Cook Inlet (Gillis, 2013, 2014; Wartes, 2015b). Additional standalone papers have also been released recently, including a noteworthy overview of Cook Inlet geology by LePain and others (2013) that incorporates original data from DGGS-led studies conducted throughout Cook Inlet since 2006.

\section{GEOLOGIC MAPPING CAMPAIGNS}

Detailed geologic mapping is an integral component of the Iniskin-Tuxedni bays field investigations. Two major mapping campaigns - funded in part by federal STATEMAP grants-were completed during the 2013 (Gillis and others, 2014; Herriott and Wartes, 2014) and 2015 field seasons (for example, Gillis, 2016 [this volume]; Wartes and others, 2016 [this volume]). During 2015 the field crew mapped the geology between Chinitna Bay and the Johnson River (fig. 1-1), including magmatic arc rocks northwest of the Bruin Bay fault system (see fig. 1-2) and extending to the Cook Inlet coast. This map area lies immediately northeast of the Iniskin Peninsula, which was mapped in 2013 (see references above). An important aspect of our lower Cook Inlet work is the recognition of along-strike changes in the stratigraphy and structure and the implications of these changes for depositional systems and deformation along the basin margin through time and space; geologic mapping serves as the cornerstone for documenting these trends in the geology and provides the framework for detailed analyses of the sedimentology, stratigraphy, and structural geology of the Iniskin-Tuxedni area. This information yields insights into basin evolution and petroleum systems.

\section{VOLUME OVERVIEW}

Nine topical chapters (2-10) follow this introduction, and address studies carried out during the 2015 field season. Six of these chapters (2-7) report on sedimentologic and stratigraphic investigations and are organized in ascending stratigraphic order (see fig. 1-3 for reference). The final three chapters (8-10) examine the deformational history of the Iniskin-Tuxedni region. Brief context for each chapter is presented below.

- Chapter 2: LePain and others (2016a [this volume]) document nonmarine facies in the Horn Mountain Tuff Member of the Lower Jurassic Talkeetna Formation and present a depositional environment interpretation for a 45-m-thick

\footnotetext{
${ }^{1}$ Alaska Division of Geological \& Geophysical Surveys, 3354 College Rd., Fairbanks, AK 99709-3707; trystan.herriott@alaska.gov
} 


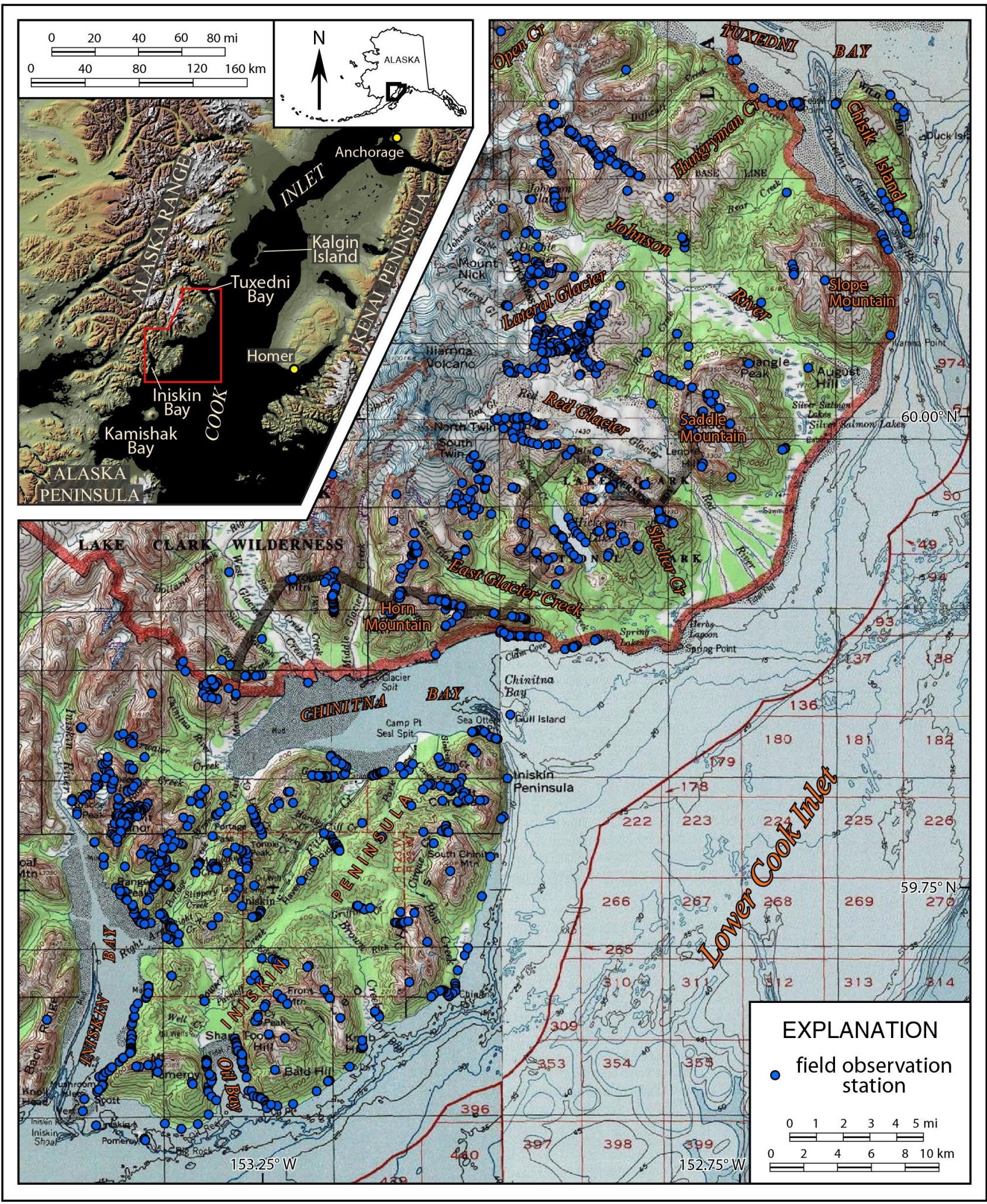

Figure 1-1. Location map for lower Cook Inlet-broadly defined as the forearc region that lies between Kalgin Island and Kamishak Bay (Fisher and Magoon, 1978; LePain and others, 2013)-and the Iniskin-Tuxedni bays study area. Geologic observations were made at 2,000 field localities by Alaska Department of Natural Resources and U.S. Geological Survey geologists as part of the lower Cook Inlet program during six field seasons in this area. This volume reports on 2015 field studies chiefly focused on the region between Chinitna and Tuxedni bays. Detailed (1:63,360-scale) geologic mapping between Chinitna Bay and the Johnson River was also completed during 2015, building on DGGS-led mapping of the Iniskin Peninsula in 2013. Geographic place names referred to in this chapter are labeled in orange text with black outline. Topographic base map from portions of U.S. Geological Survey Iliamna, Seldovia, Lake Clark, and Kenai 1:250,000-scale quadrangles; shaded-relief image modified after U.S. Geological Survey Elevation Data Set Shaded Relief of Alaska poster (available for download at http://eros.usgs.gov/alaska-0). Abbreviation: $\mathrm{Cr}=$ Creek. 


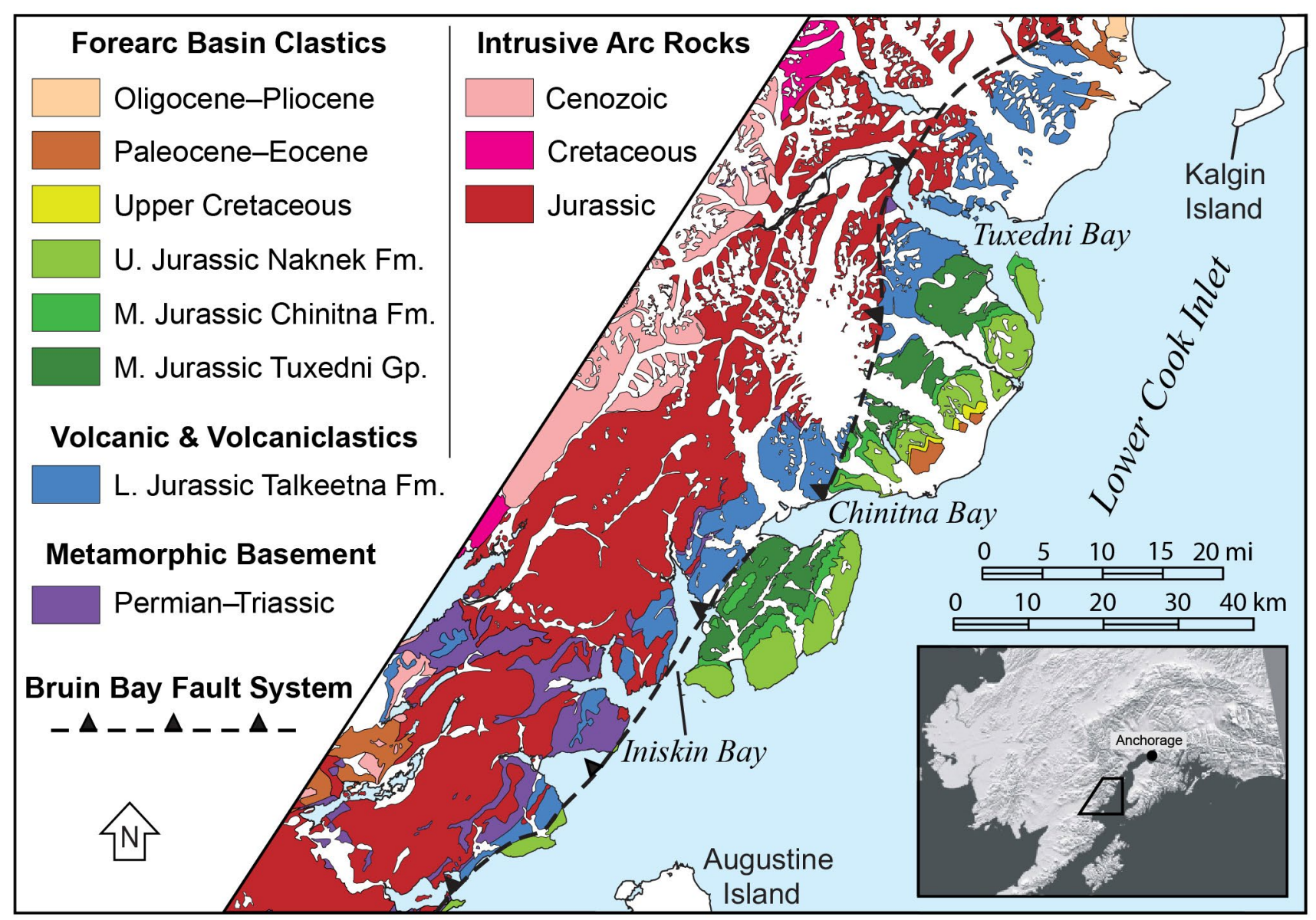

Figure 1-2. Simplified geologic map of lower Cook Inlet. The Bruin Bay fault system in this region is generally regarded as the northwestern margin of the forearc basin, with Middle Jurassic and younger forearc basin strata lying to the southeast and Lower Jurassic and younger arc rocks dominantly to the northwest (see LePain and others, 2013). Figure from Wartes (2015a); geologic mapping modified from regional compilation by Wilson and others (2009; see also Wilson and others, 2012). Abbreviations: Fm. = Formation; Gp. = Group; L. = Lower; M. = Middle; U. = Upper.

interval near Horn Mountain (fig. 1-1). This work provides a better understanding of depositional systems in the Talkeetna Formation as well as additional details regarding local paleogeographic constraints for this early manifestation of the magmatic arc.

- Chapter 3: LePain and others (2016b [this volume]) continue an investigation of the Middle Jurassic Red Glacier Formation (see also Stanley and others, 2013; LePain and Stanley, 2015), a stratigraphic unit that is correlative to source rocks for Cook Inlet's oil (see references above). This paper presents a sedimentologic analysis for the lower several hundred meters of the formation south of Hungryman Creek (fig. 1-1). The authors' interpreted depositional setting for this locality contrasts sharply with the Lateral Glacier (fig. 1-1) locality of LePain and Stanley (2015), suggesting along-basin-margin changes in paleo-water depth and depositional setting recorded by this economically significant formation.

- Chapter 4: Helmold and others (2016 [this volume]), in a companion study to chapter 3, present preliminary observations and interpretations of petrology and reservoir quality for sandstones in the Red Glacier Formation at the Hungryman Creek (fig. 1-1) locality. Despite the age and volcanogenic composition of these strata, the authors note that comparable facies in the subsurface may serve as tight-gas reservoirs. Furthermore, interfingering of lithologically similar sandstones with oil-prone source rocks could yield continuous oil accumulations in the subsurface.

- Chapter 5: Herriott and others (2016a [this volume]) analyze the stratigraphic architecture of the Middle Jurassic Paveloff Siltstone Member (Chinitna Formation) in the Johnson River area, between Slope and Saddle mountains (fig. 1-1). This paper documents sand-prone, channelized depositional systems that likely exported coarse detritus to downdip settings, where such deposits may host oil accumulations in the subsurface of Cook Inlet. Similar sand-rich facies in the Paveloff are oil stained in outcrop at Chinitna Bay (Wartes and Herriott, 2015). 
- Chapter 6: Herriott and others (2016b [this volume]) continue to examine the stratigraphy of deep-water deposits in the Upper Jurassic Snug Harbor Siltstone and Pomeroy Arkose Members (Naknek Formation) (see also Wartes and others, 2013a; Herriott and Wartes, 2014; Herriott and others, 2015a). This chapter documents a newly discovered paleo-canyon at Chisik Island (fig. 1-1), with implications for bypass and accumulation of sand in deep-water settings as well as the sequence stratigraphic framework of the Naknek Formation (see also Herriott and others, 2015b). Similar deep-water depositional systems known throughout the world are important reservoirs for oil and gas.

- Chapter 7: Gillis (2016 [this volume]) documents porosity-hosted residual oil in sandstone of the Shelter Creek area (fig. 1-1). This outcrop lies in a Campanian to Maastrichtian(?) interval that is likely equivalent to Upper Cretaceous strata that are oil stained in outcrop elsewhere in Cook Inlet (for example, LePain and others, 2012; Wartes and others,

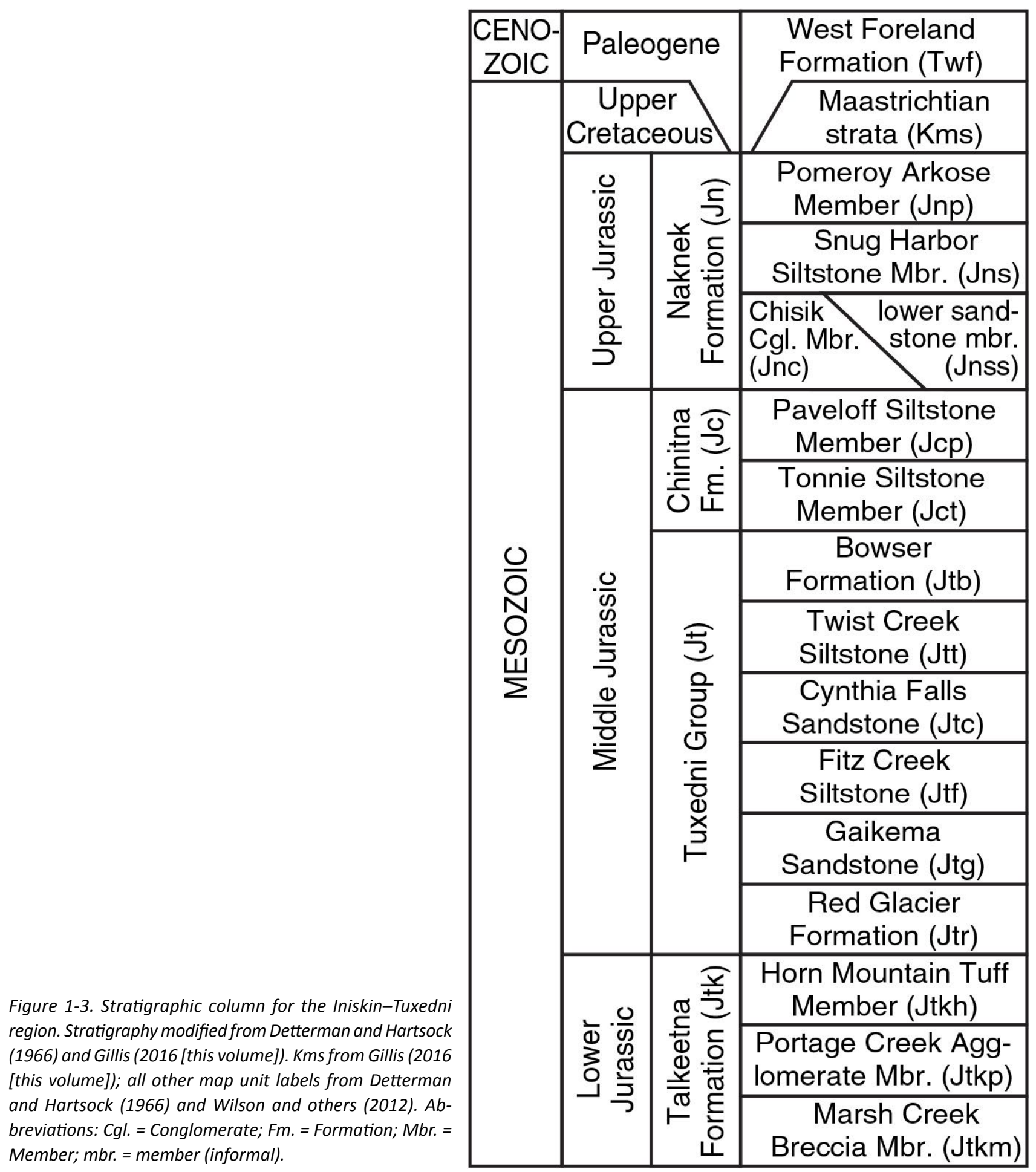


2013b; Herriott and others, 2013) and yield oil shows in wells. The relatively quartz-rich nature of Upper Cretaceous deposits in Cook Inlet and their documented association with porosity-hosted oil suggest the potential for the interval to contain conventional accumulations of oil. This chapter also presents new constraints for timing of deformation in the basin, which is critical to evaluating petroleum migration and trap formation.

- Chapter 8: Wartes and others (2016 [this volume]) introduce new geologic mapping of the east-trending ridge between East Glacier Creek and the north shore of Chinitna Bay (fig. 1-1). Their mapping extends across the trace of the Bruin Bay fault system and is immediately north of a kilometer-scale, right-stepping bend, step-over, or offset along this regionally significant structure. The paper proposes several permissible models that may account for the large-scale structural relations across Chinitna Bay that have implications for known fracture-associated occurrences of oil and gas on the Iniskin Peninsula.

- Chapter 9: Rosenthal and others (2016 [this volume]) continue a regional fractures study (see also Gillis and others, 2013a; Rosenthal and others, 2015) and present results from two field localities in the Oil Bay area (fig. 1-1). These authors report higher fracture intensities at their Paveloff Siltstone Member (Chinitna Formation) locality than at their Pomeroy Arkose Member (Naknek Formation) locality, inferring that grain size is the primary control of fracture intensity. This work relates to unconventional reservoir prospectivity in the basin and development of effective well stimulation programs for potential reservoirs.

- Chapter 10: Betka and Gillis (2016 [this volume]) continue an investigation of the Bruin Bay fault system (see also Gillis and others, 2013b; Betka and Gillis 2014a, 2014b, 2015). New observations from fault exposures near Red Glacier, Johnson River, and Open Creek (fig. 1-1) suggest left transpression along this extent of the fault system. Fault kinematics from the three field localities record a transition from left-reverse-slip in the south to left-strike-slip in the north, probably reflecting the Bruin Bay fault system's change in strike north of the Johnson River. This work aims to constrain the nature and timing of deformation along the basin's northwest margin, which are essential elements to a comprehensive understanding of Cook Inlet petroleum systems.

\section{ACKNOWLEDGMENTS}

Primary funding for the lower Cook Inlet work is provided by the State of Alaska. Geologic mapping during the 2013 and 2015 field seasons was supported by the U.S. Geological Survey's National Cooperative Geologic Mapping Program (NCGMP) through STATEMAP (award numbers G13AC00157 and G15AC00199). The mapping crew thanks NCGMP Coordinator Doug Howard for visiting the study area during July 2015.

Land access for this work was permitted by Lake Clark National Park \& Preserve, Cook Inlet Region, Inc., and the following Alaska Native village corporations: Chickaloon, Knik, Ninilchik, Salamatof, Seldovia, and Tyonek. Thanks to Buck Mangipane and Jeff Shearer at Lake Clark National Park \& Preserve and Jason Brune and Tanisha Gleason of Cook Inlet Region, Inc., for their assistance in permitting.

Pathfinder Aviation helicopter pilot Merlin "Spanky" Handley skillfully and safely transported field personnel during the 2015 field season. The crew thanks owners and staff of the former cannery on Chisik Island for their hospitality.

Nina Harun compiled station data plotted on figure 1-1 and Marwan Wartes rendered a version of figure 1-2. Paula Davis and Joni Robinson deftly guided this volume through the publication process with timely attention to detail. Steve Masterman carefully reviewed proofs for each of the volume's chapters. David LePain provided instructive comments for this introduction and reviewed all chapters in this volume except those he authored.

\section{REFERENCES CITED}

Betka, P.M., and Gillis, R.J., 2014a, Preliminary kinematic evidence for right-lateral slip along a system of steeply-dipping faults in the hanging wall of the Bruin Bay fault, Iniskin Peninsula, lower Cook Inlet, Alaska, in Gillis, R.J., ed., Cook Inlet program 2013 field studies-Observations and preliminary interpretations from new 1:63,360-scale geologic mapping of the Iniskin Peninsula, lower Cook Inlet, Alaska: Alaska Division of Geological \& Geophysical Surveys Preliminary Interpretive Report 2014-2-4, p. 17-22. doi:10.14509/27309

2014b, Preliminary characterization of brittle deformation on the Iniskin Peninsula - Implications for the kinematic history of the Bruin Bay fault system, lower Cook Inlet, Alaska: Alaska Division of Geological \& Geophysical Surveys Preliminary Interpretive Report 2014-5, 14 p. doi:10.14509/29130

2015, The superposition of strike-slip and reverse-slip faults in the Bruin Bay fault system, Ursus Head, lower Cook Inlet, in Wartes, M.A., ed., Energy-related studies during the 2014 field season, western Cook Inlet, Alaska: Alaska Division of Geological \& Geophysical Surveys Preliminary Interpretive Report 2015-5-2, p. 5-8. doi:10.14509/29457 
Betka, P.M., and Gillis, R.J., 2016 (this volume), Observations on the Bruin Bay fault system between Chinitna and Tuxedni bays, Cook Inlet, Alaska, in Herriott, T.M., ed., Petroleum-related geologic studies in lower Cook Inlet during 2015, Iniskin-Tuxedni region, south-central Alaska: Alaska Division of Geological \& Geophysical Surveys Preliminary Interpretive Report 2016-1, p. 73-78. doi: 10.14509/29544

Blasko, D.P., 1976, Oil and gas exploration on the Iniskin Peninsula, Alaska: U.S. Bureau of Mines Open-File Report 69$76,19 \mathrm{p}$.

Detterman, R.L., and Hartsock, J.K., 1966, Geology of the Iniskin-Tuxedni region, Alaska: U.S. Geological Survey Professional Paper 512, 78 p., 6 sheets, scale 1:63,360.

Fisher, M.A., and Magoon, L.B., 1978, Geologic framework of lower Cook Inlet, Alaska: American Association of Petroleum Geologists Bulletin, v. 62, no. 3, p. 373-402. doi:10.1306/C1EA4851-16C9-11D7-8645000102C1865D

Gillis, R.J., ed., 2013, Overview of 2012 field studies - Upper Alaska Peninsula and west side of lower Cook Inlet, Alaska: Alaska Division of Geological \& Geophysical Surveys Preliminary Interpretive Report 2013-1, 48 p. doi:10.14509/24824

Gillis, R.J., ed., 2014, Cook Inlet program 2013 field studies - Observations and preliminary interpretations from new 1:63,360-scale geologic mapping of the Iniskin Peninsula, lower Cook Inlet, Alaska: Alaska Division of Geological \& Geophysical Surveys Preliminary Interpretive Report 2014-2, 31 p. doi:10.14509/27303

Gillis, R.J., 2016 (this volume), Discovery of a new sandstone with residual oil Maastrichtian(?) strata at Shelter Creek, lower Cook Inlet, Alaska, in Herriott, T.M., ed., Petroleum-related geologic studies in lower Cook Inlet during 2015, Iniskin-Tuxedni region, south-central Alaska: Alaska Division of Geological \& Geophysical Surveys Preliminary Interpretive Report 2016-1, p. 51-58. doi:10.14509/29541

Gillis, R.J., Maley, M.R., Frohman, R.A., and Peterson, C.S., 2013a, Fracture studies in Upper Cretaceous and Upper Jurassic strata on the upper Alaska Peninsula and lower Cook Inlet, in Gillis, R.J., ed., Overview of 2012 field studies-Upper Alaska Peninsula and west side of lower Cook Inlet, Alaska: Alaska Division of Geological \& Geophysical Surveys Preliminary Interpretive Report 2013-1D, p. 13-17. doi:10.14509/24847

Gillis, R.J., Swenson, R.F., Wartes, M.A., and Frohman, R.A., 2013b, Reconnaissance investigations of the Bruin Bay fault system along the western margin of lower Cook Inlet and upper Alaska Peninsula, in Gillis, R.J., ed., Overview of 2012 field studies - Upper Alaska Peninsula and west side of lower Cook Inlet, Alaska: Alaska Division of Geological \& Geophysical Surveys Preliminary Interpretive Report 2013-1G, p. 33-37. doi:10.14509/24850

Gillis, R.J., Wartes, M.A., Herriott, T.M., Bull, K.F., Decker, P.L., and Betka, P.M., 2014, Overview of new 1:63,360-scale geologic mapping of the Iniskin Peninsula, lower Cook Inlet, Alaska, in Gillis, R.J., ed., Cook Inlet program 2013 field studies - Observations and preliminary interpretations from new 1:63,360-scale geologic mapping of the Iniskin Peninsula, lower Cook Inlet, Alaska: Alaska Division of Geological \& Geophysical Surveys Preliminary Interpretive Report 2014-2-1, p. 3-6. doi:10.14509/27306

Helmold, K.P., LePain, D.L., and Stanley, R.G., 2016 (this volume), Sedimentary petrology and reservoir quality of the Middle Jurassic Red Glacier Formation, Cook Inlet forearc basin-Initial impressions, in Herriott, T.M., ed., Petroleumrelated geologic studies in lower Cook Inlet during 2015, Iniskin-Tuxedni region, south-central Alaska: Alaska Division of Geological \& Geophysical Surveys Preliminary Interpretive Report 2016-1, p. 33-37. doi:10.14509/29537

Herriott, T.M., and Wartes, M.A., 2014, Geologic-mapping-based observations of the Middle Jurassic Chinitna Formation and Upper Jurassic Naknek Formation in the Tilted Hills, Iniskin Peninsula, Cook Inlet, Alaska: Alaska Division of Geological \& Geophysical Surveys Preliminary Interpretive Report 2014-3, 23 p. doi:10.14509/27305

Herriott, T.M., Wartes, M.A., Stanley, R.G., Lillis, P.G., Helmold, K.P., Decker, P.L., and Gillis, R.J., 2013, Oil-stained sandstones of the Upper Jurassic Naknek Formation and Upper Cretaceous Kaguyak Formation, Kamishak Bay area, lower Cook Inlet, Alaska [poster]: AAPG Pacific Section Meeting, Monterey, CA, April 23, 2013: Alaska Division of Geological \& Geophysical Surveys, 1 sheet. doi:10.14509/25139

Herriott, T.M., Decker, P.L., and Wartes, M.A., 2015a, Evidence of a submarine canyon in the Snug Harbor Siltstone and Pomeroy Arkose Members, Naknek Formation, south-central Alaska - Implications for the distribution of coarse-grained sediment in Upper Jurassic strata of Cook Inlet, in Wartes, M.A., ed., Energy-related studies during the 2014 field season, western Cook Inlet, Alaska: Alaska Division of Geological \& Geophysical Surveys Preliminary Interpretive Report 2015-5-9, p. 57-62. doi:10.14509/29464

Herriott, T.M., Wartes, M.A., and Decker, P.L., 2015b, Deep-water canyons in the Snug Harbor Siltstone and Pomeroy Arkose Members, Naknek Formation, Alaska - New insights into the sequence stratigraphy of the Late Jurassic Cook Inlet forearc basin [presentation]: Geological Society of America, Cordilleran Section Annual Meeting, May 11-13, 2015, Anchorage, Alaska: Alaska Division of Geological \& Geophysical Surveys, 37 p. doi:10.14509/29443 
Herriott, T.M., Wartes, M.A., and Decker, P.L., 2016b (this volume), Record of a Late Jurassic deep-water canyon at Chisik Island, south-central Alaska: Further delineation of Naknek Formation depositional systems in lower Cook Inlet, in Herriott, T.M., ed., Petroleum-related geologic studies in lower Cook Inlet during 2015, Iniskin-Tuxedni region, southcentral Alaska: Alaska Division of Geological \& Geophysical Surveys Preliminary Interpretive Report 2016-1, p. 45-49. doi: $10.14509 / 29540$

Herriott, T.M., Wartes, M.A., Decker, P.L., and Harun, N.T., 2016a (this volume), Preliminary stratigraphic architecture of the Middle Jurassic Paveloff Siltstone Member, Chinitna Formation, Tuxedni Bay area, Cook Inlet, Alaska, in Herriott, T.M., ed., Petroleum-related geologic studies in lower Cook Inlet during 2015, Iniskin-Tuxedni region, south-central Alaska: Alaska Division of Geological \& Geophysical Surveys Preliminary Interpretive Report 2016-1, p. 39-44. doi: $10.14509 / 29539$

LePain, D.L., and Stanley, R.G., 2015, Stratigraphic reconnaissance of the Middle Jurassic Red Glacier Formation, Tuxedni Group, at Red Glacier, Cook Inlet, Alaska, in Wartes, M.A., ed., Energy-related studies during the 2014 field season, western Cook Inlet, Alaska: Alaska Division of Geological \& Geophysical Surveys Preliminary Interpretive Report 2015-5-5, p. 23-28. doi:10.14509/29460

LePain, D.L., Lillis, P.G., Helmold, K.P., and Stanley, R.G., 2012, Migrated hydrocarbons in exposure of Maastrichtian nonmarine strata near Saddle Mountain, lower Cook Inlet, Alaska: Alaska Division of Geological \& Geophysical Surveys Report of Investigation 2012-1, 13 p. doi: $10.14509 / 23943$

LePain, D.L., Stanley, R.G., Helmold, K.P., and Shellenbaum, D.P., 2013, Geologic framework and petroleum systems of Cook Inlet basin, south-central Alaska, in Stone, D.M., and Hite, D.M., eds., Oil and Gas Fields of the Cook Inlet Basin: American Association of Petroleum Geologists Memoir 104, p. 37-116.

LePain, D.L., Stanley, R.G., and Helmold, K.P., 2016a (this volume), Nonmarine facies in the Late Triassic(?) to Early Jurassic Horn Mountain Tuff Member of the Talkeetna Formation, Horn Mountain, lower Cook Inlet basin, Alaska, in Herriott, T.M., ed., Petroleum-related geologic studies in lower Cook Inlet during 2015, Iniskin-Tuxedni region, south-central Alaska: Alaska Division of Geological \& Geophysical Surveys Preliminary Interpretive Report 2016-1, p. 9-20. doi: $\underline{10.14509 / 29535}$

2016 b (this volume), Reconnaissance stratigraphy of the Red Glacier Formation (Middle Jurassic) near Hungryman Creek, Cook Inlet basin, Alaska, in Herriott, T.M., ed., Petroleum-related geologic studies in lower Cook Inlet during 2015, Iniskin-Tuxedni region, south-central Alaska: Alaska Division of Geological \& Geophysical Surveys Preliminary Interpretive Report 2016-1, p. 21-31. doi:10.14509/29536

Martin, G.C., 1905, The petroleum fields of the Pacific coast of Alaska, with an account of the Bering River coal deposits: U.S. Geological Survey Bulletin 250, 64 p.

Nelson, Kristen, 2014, Cook Inlet license draws competitive bids: Petroleum News, v. 19, no. 26, p. 6 and 10. http://www. petroleumnews.com/pnads/670721839.shtml, accessed December 15, 2015.

Rosenthal, J.L., Betka, P.M., Gillis, R.J., and Nadin, E.S., 2015, Preliminary investigation of fracture populations in Mesozoic strata of the Cook Inlet forearc basin-Iniskin Peninsula and Lake Clark National Park, Alaska, in Wartes, M.A., ed., Energy-related studies during the 2014 field season, western Cook Inlet, Alaska: Alaska Division of Geological \& Geophysical Surveys Preliminary Interpretive Report 2015-5-3, p. 9-13. doi:10.14509/29458

Rosenthal, J.L., Betka, P.M., Gillis, R.J., and Nadin, E.S., 2016 (this volume), Fracture intensity in the Paveloff Siltstone Member (Chinitna Formation) and Pomeroy Arkose Member (Naknek Formation), Iniskin Peninsula, Alaska: Implications for hydrocarbon migration in Cook Inlet basin, in Herriott, T.M., ed., Petroleum-related geologic studies in lower Cook Inlet during 2015, Iniskin-Tuxedni region, south-central Alaska: Alaska Division of Geological \& Geophysical Surveys Preliminary Interpretive Report 2016-1, p. 67-72. doi:10.14509/29543

Stanley, R.G., Charpentier, R.R., Cook, T.A., Houseknecht, D.W., Klett, T.R., Lewis, K.A., Lillis, P.G., Nelson, P.H., Phillips, J.D., Pollastro, R.M., Potter, C.J., Rouse, W.A., Saltus, R.W., Schenk, C.J., Shah, A.K., and Valin, Z.C., 2011, Assessment of undiscovered oil and gas resources of the Cook Inlet region, south-central Alaska, 2011: U.S. Geological Survey Fact Sheet 2011-3068, 2 p.

Stanley, R.G., Herriott, T.M., LePain, D.L., Helmold, K.P., and Peterson, C.S., 2013, Reconnaissance studies of potential petroleum source rocks in the Middle Jurassic Tuxedni Group near Red Glacier, eastern slope of Iliamna Volcano, in Gillis, R.J., ed., Overview of 2012 field studies - Upper Alaska Peninsula and west side of lower Cook Inlet, Alaska: Alaska Division of Geological \& Geophysical Surveys Preliminary Interpretive Report 2013-1B, p. 5-9. doi:10.14509/24845

Wartes, M.A., 2015a, An introduction to 2014 field studies in western Cook Inlet, Alaska, in Wartes, M.A., ed., Energyrelated studies during the 2014 field season, western Cook Inlet, Alaska: Alaska Division of Geological \& Geophysical Surveys Preliminary Interpretive Report 2015-5-1, p. 1-4. doi:10.14509/29456 
Wartes, M.A., ed., 2015b, Energy-related studies during the 2014 field season, western Cook Inlet, Alaska: Alaska Division of Geological \& Geophysical Surveys Preliminary Interpretive Report 2015-5, 62 p. doi:10.14509/29455

Wartes, M.A., and Herriott, T.M., 2015, Oil-stained sandstone in the Middle Jurassic lower Paveloff Siltstone Member of the Chinitna Formation-Exploring the potential role of facies variations in controlling diagenesis and reservoir quality in western Cook Inlet, Alaska: Alaska Division of Geological \& Geophysical Surveys Preliminary Interpretive Report 2015-7, 9 p. doi:10.14509/29533

Wartes, M.A., Decker, P.L., Stanley, R.G., Herriott, T.M., Helmold, K.P., and Gillis, R.J., 2013b, Preliminary stratigraphy and facies analysis of the Upper Cretaceous Kaguyak Formation, including a brief summary of newly discovered oil stain, upper Alaska Peninsula, in Gillis, R.J., ed., Overview of 2012 field studies-Upper Alaska Peninsula and west side of lower Cook Inlet, Alaska: Alaska Division of Geological \& Geophysical Surveys Preliminary Interpretive Report 2013-1F, p. 25-32. doi:10.14509/24849

Wartes, M.A., Gillis, R.J., and Harun, N.T., 2016 (this volume), Revised mapping of the Upper Jurassic Naknek Formation in a footwall syncline associated with the Bruin Bay fault system, Chinitna Bay region, western Cook Inlet, Alaska, in Herriott, T.M., ed., Petroleum-related geologic studies in lower Cook Inlet during 2015, Iniskin-Tuxedni region, south-central Alaska: Alaska Division of Geological \& Geophysical Surveys Preliminary Interpretive Report 2016-1, p. 59-66. doi: $10.14509 / 29542$

Wartes, M.A., Herriott, T.M., Helmold, K.P., and Gillis, R.J., 2013a, Preliminary stratigraphic interpretation of the Naknek Formation-Evidence for Late Jurassic activity on the Bruin Bay fault, Iniskin Peninsula, lower Cook Inlet, in Gillis, R.J., ed., Overview of 2012 field studies_-Upper Alaska Peninsula and west side of lower Cook Inlet, Alaska: Alaska Division of Geological \& Geophysical Surveys Preliminary Interpretive Report 2013-1H, p. 39-46. doi:10.14509/24851

Wilson, F.H., Hults, C.P., Schmoll, H.R., Haeussler, P.J., Schmidt, J.M., Yehle, L.A., and Labay, K.A., compilers, 2009, Preliminary geologic map of the Cook Inlet region, Alaska: U.S. Geological Survey Open-File Report 2009-1108, 52 p., 2 sheets, scale 1:250,000.

2012, Geologic map of the Cook Inlet region, Alaska, including parts of the Talkeetna, Talkeetna Mountains, Tyonek, Anchorage, Lake Clark, Kenai, Seward, Iliamna, Seldovia, Mount Katmai, and Afognak quadrangles: U.S. Geological Survey Scientific Investigations Map 3153, 76 p., 2 sheets, scale 1:250,000. 